\title{
Tingkat Kepuasan Masyarakat terhadap Konstruksi Pengendali Banjir di Kawasan Sungai Bungus Kecamatan Bungus Teluk Kabung
}

\author{
M. Arifin ${ }^{1 *}$, Taufika Ophiyandri ${ }^{2}$, Bambang Istijono ${ }^{3}$ \\ ${ }^{1}$ Magister Teknik Sipil Universitas Andalas \\ ${ }^{2,3}$ Teknik Sipil Universitas Andalas \\ Correspondence email: *arifin.workmail@gmail.com, ${ }^{2}$ ophiyandri@ft.unand.ac.id, ${ }^{3}$ bistijono1452@yahoo.com
}

\begin{abstract}
Abstrak. Banjir adalah suatu kondisi dimana tidak tertampungnya air dalam saluran pembuang (palung sungai) atau terhambatnya aliran air di dalam saluran pembuang, sehingga meluap menggenangi daerah (dataran banjir) sekitarnya. Langkah yang dilakukan pemerintah adalah dengan pengadaan konstruksi pengendali banjir dengan tujuan mengurangi bahkan menghilangkan ancaman banjir tersebut. Konstruksi pengendali banjir yang sudah ada di sungai tersebut adalah normalisasi dan checkdam. Penelitian ini membahas tentang kepuasan masyarakat terhadap pengadaan konstruksi pengendali banjir di Sungai Bungus tepatnya pada Kecamatan Bungus Teluk Kabung, Kota Padang. Jenis penelitian ini adalah penelitian deskriptif kuantitatif dengan metode survey. Hasil studi menyimpulkan bahwa manfaat dan kepuasan yang dirasakan masyarakat berbeda dari kedua konstruksi pengendali banjir yang ada di Sungai Bungus tersebut. Masyarakat merasa tidak puas dengan konstruksi normalisasi dan dirasakan belum bermanfaat. Namun, setelah adanya konstruksi checkdam masyarakat menjadi puas dan masyarakat secara keseluruhan sudah merasakan adanya manfaat dari konstruksi tersebut.
\end{abstract}

Kata Kunci: Banjir, Konstruksi Pengendali Banjir, Normalisasi, Checkdam

\section{PENDAHULUAN}

Menurut Peraturan Kepala Badan Nasional Penanggulangan Bencana Nomor 02 Tahun 2012, bencana adalah kejadian atau rangkaian kejadian yang mengganggu dan mengancam kehidupan dan penghidupan masyarakat disebabkan, oleh faktor alam dan/atau non alam maupun faktor manusia sehingga mengakibatkan timbulnya korban material, kerusakan lingkungan, mental atau psikologis bahkan jiwa manusia. Terdapat 13 jenis ancaman bencana yang ada di Indonesia secara umum, diantaranya gempa bumi, tsunami, banjir, tanah longsor, letusan gunung api, gelombang ekstrim dan abrasi, cuaca ekstrim, kekeringan, kebakaran hutan dan lahan, kebakaran gedung dan pemukiman, epidemi dan wabah penyakit, gagal teknologi, dan konflik sosial. Dengan kondisi tersebut, maka diperlukan penanggulangan bencana yang baik agar kehidupan dan penghidupan masyarakat dapat berjalan dengan selayaknya.

Banjir adalah suatu kondisi dimana tidak tertampungnya air dalam saluran pembuang (palung sungai) atau terhambatnya aliran air di dalam saluran pembuang, sehingga meluap menggenangi daerah (dataran banjir) sekitarnya (Suripin dalam Bahtiar ,2010). Banjir merupakan salah satu bencana yang sering menjadi langganan pada kawasan sungai yang ada di Indonesia. Menurut data BNPB tahun 2018, bencana banjir menempati urutan pertama kejadian bencana alam yang terjadi dalam kurun waktu 10 tahun terakhir yaitu dengan jumlah 6053 kejadian. Dapat disimpulkan banjir adalah bencana yang sering menjadi permasalahan bagi masyarakat yang berada di daerah sekitar sungai dikarenakan beberapa kawasan sungai salah satunya memiliki elevasi rendah atau yang berdekatan dengan permukaan sungai dan pada akhirnya menimbulkan kerugian bagi masyarakat.

Berdasarkan data BNPB tahun 2018, jumlah kejadian bencana banjir di Sumatera Barat berjumlah 198 kejadian dalam kurun waktu 10 tahun terakhir, Kota Padang juga termasuk kawasan langganan banjir ketika terjadi hujan intensitas tinggi di beberapa wilayah dengan jumlah 21 kejadian dalam 10 tahun terakhir. Dengan adanya ancaman banjir tersebut, maka pemerintah berusaha mengurangi dampak dari bencana banjir agar masyarakat tidak menjadi korban dari bencana banjir ini. Langkah yang dilakukan pemerintah salah satunya mengadakan konstruksi pengendali banjir guna mengurangi bahkan menghilangkan ancaman banjir tersebut.

Pemerintah Kota Padang sudah melakukan beberapa pengadaan konstruksi pengendali banjir untuk mengatasi banjir salah satunya di Sungai Bungus. Sungai Bungus memiliki ketinggian antara $0-850 \mathrm{mdpl}$ dan lima kelurahan terletak di daerah pantai dengan kelandaian kurang dari 15 derajat dan tidak melebihi 17 mdpl menjadikan wilayah ini memiliki kemungkinan besar terjadi bencana banjir.

Sungai Bungus dengan panjang sekitar 16,2 Km pernah beberapa kali mengalami banjir dan sudah memiliki perkuatan dinding sungai pada tahun 2011, namun masih belum mampu mengatasi banjir secara maksimal. Pemerintah berusaha lagi untuk mengatasi permasalahan banjir yang ada di Sungai Bungus ini dengan konstruksi Checkdam yang telah selesai pada tahun 2016.

Pengadaan konstruksi tersebut tentunya diharapkan tepat guna dan bermanfaat bagi masyarakat yang berdampak langsung dari kontruksi ini. Untuk mengetahui apakah konstruksi tersebut berdampak langsung kepada 
masyarakat salah satunya dapat diketahui dari tingkat kepuasan masyarakat di sekitar sungai yang berdampak langsung.

Berdasarkan latar belakang tersebut, penulis tertarik membahas tentang kepuasan masyarakat terhadap pengadaan konstruksi pengendali banjir di Sungai Bungus tepatnya pada Kecamatan Bungus Teluk Kabung, Kota Padang.

Tujuan penelitian ini adalah: 1) Mengetahui manfaat yang diperoleh masyarakat dari infrastruktur pengendali banjir yang ada di Sungai Bungus. 2) Mengetahui kepuasan masyarakat dari adanya infrastruktur pengendali banjir.

Berdasarkan latar belakang di atas, maka terdapat beberapa batasan masalah sebagai berikut: Objek penelitian pada penelitian ini adalah menganalisa kepuasan masyarakat terhadap proyek konstruksi pemerintah berupa konstruksi pengendali banjir yang ada di Kota Padang, khususnya kawasan Sungai Bungus Kecamatan Bungus Teluk Kabung. Konstruksi pengendali banjir yang sudah ada tersebut berupa normalisasi dan checkdam.

Masyarakat yang menjadi objek penelitian adalah masyarakat yang terdata resmi kependudukan dan berdomisili minimal sejak tahun 2010 dengan usia minimal 17 tahun yang berada di kawasan yang pernah terkena dampak banjir tepatnya kelurahan yang dilalui oleh Sungai Bungus yaitu Kelurahan Bungus Selatan, Bungus Barat dan Kelurahan Bungus Timur yang selanjutnya disebut sebagai responden, dengan jumlah 100 orang responden.

\section{METODE}

Objek penelitian pada penelitian ini adalah menganalisa kepuasan masyarakat terhadap proyek konstruksi pemerintah berupa konstruksi pengendali banjir yaitu normalisasi dan checkdam yang ada di Kota Padang, khususnya kawasan Sungai Bungus Kecamatan Bungus Teluk Kabung dengan waktu penelitian yang akan dilaksanakan dari bulan April sampai bulan Juli Tahun 2018.

Jenis penelitian ini adalah penelitian deskriptif kuantitatif dengan metode survey untuk mengetahui manfaat dan kepuasan masyarakat terhadap konstruksi pengendali banjir. Metode penelitian kuantitatif dapat diartikan sebagai metode penelitian yang berlandaskan pada filsafat positivisme, digunakan untuk meneliti pada populasi atau sampel tertentu (Sugiyono, 2008).

Penelitian survey merupakan penelitian yang menggunakan kuesioner sebagai instrument penelitian, penelitian survei termasuk kelompok penelitian kuantitatif (Prasetyo, 2012). Kuesioner yang digunakan dalam penelitian ini adalah kuesioner terbuka dengan artian isi kuesioner tergantung dari jawaban responden dimana responden sendiri adalah masyarakat yang pernah merasakan dampak bencana banjir yang terdata resmi sebagai warga Kecamatan Bungus Teluk Kabung. Wawancara terbuka dilakukan kepada dinas pemerintahan untuk mendapatkan data yang menunjang kesuksesan penelitian ini.

\section{Sampel}

Pada Kecamatan Bungus Teluk Kabung terdapat enam kelurahan, namun hanya tiga kelurahan yang dilalui oleh Sungai Bungus yaitu Kelurahan Bungus Selatan, Bungus Barat dan Kelurahan Bungus Timur. Oleh karena itu yang menjadi sampel pada penelitian ini adalah masyarakat pada tiga kelurahan tersebut.

Responden yang dijadikan sampel pada penelitian ini adalah yang memenuhi kriteria inklusi yaitu :

1. Masyarakat yang terdata resmi sebagai warga Kecamatan Bungus Teluk Kabung, khususnya yang bertempat tinggal di tiga kelurahan tersebut dan dekat dengan badan sungai serta pernah merasakan dampak bencana banjir.

2. Masyarakat yang berumur minimal 17 tahun dan bersedia untuk menjadi responden.

3. Masyarakat yang berdomisili minimal sejak tahun 2010.

Sampel pada penelitian ini berjumlah 100 orang responden yang dihitung dangan menggunakan Rumus Slovin (Supranjo, 1998).

\section{Survey Pendahuluan ke Lapangan}

Survey pendahuluan bertujuan untuk mengamati kondisi lapangan tempat penelitian yaitu di Sungai Bungus, Kecamatan Bungus Teluk Kabung, Kota Padang. Pengamatan ini juga dilakukan untuk mengetahui kehidupan dan penghidupan masyarakat di sekitar lokasi penelitian tersebut dengan tujuan mendapatkan kondisi sosial masyarakat pada daerah penelitian.

\section{Data Sekunder}

Data sekunder pada penelitian ini didapatkan dari dokumen - dokumen yang dikumpulkan melalui :

1. Data riwayat banjir daerah Sungai Bungus pada tahun 2018 dari website Data Informasi Bencana Indonesia (DIBI) oleh Badan Nasional Penanggulangan Bencana (BNPB).

2. Data kependudukan masyarakat sekitar Sungai Bungus didapatkan dari BPS Kota Padang dan pemerintahan daerah setempat pada tahun 2017. 


\section{Data Primer}

Data primer dalam penelitian ini diperoleh dari hasil kuesioner yang akan dirancang sesuai dengan kriteria kerugian paska bencana banjir sebelum dan sesudah adanya konstruksi pengendali banjir di kawasan tersebut. Kawasan penelitian nantinya akan didasari dari wilayah yang pernah terkena banjir berdasarkan data sekunder. Kuesioner sendiri akan disajikan dengan melakukan wawancara kepada masyarakat sekitar lokasi penelitian dan diusahakan agar komunikasi berjalan lancar seolah masyarakat yang diwawancarai tidak sadar sedang diwawancarai dengan tujuan data yang didapatkan objektif tanpa rekayasa.

\section{Metode Analisis}

Dengan metode analisis, manfaat dan kepuasan yang dirasakan masyarakat pada kawasan Sungai Bungus dapat diketahui. Hal ini dapat diperoleh dengan melakukan wawancara kepada responden yang merupakan masyarakat sekitar kawasan Sungai Bungus. Responden dipilih secara acak dengan jumlah yang didapatkan dari rumus slovin. Isi wawancara sendiri disusun pada kuesioner yang sudah dibuat sebelumnya.

Metode statistik deskriptif digunakan dalam analisis pada penelitian ini. Merupakan cara tersistim yang berkaitan dengan pengumpulan dan penyajian beberapa data yang diolah sedemikian rupa sehingga diperoleh informasi yang bermanfaat pada penelitian ini. Pengolahan data menggunakan software statistik yaitu Rstudio. Dari software tersebut nantinya didapatkan rata - rata, nilai tertinggi, nilai terendah serta persentase dari data yang diperoleh yang pada akhirnya disajikan dalam bentuk grafik. Mendapatkan distribusi normal suatu data masing masing variabel data yang diuji dengan menggunakan metode uji regresi, menguji tingkat signifikan perbandingan antara variabel dan menampilkan dalam bentuk tabel dan grafik dari hasil analisis program tersebut.

\section{Parameter Penelitian}

Dari pengumpulan data awal tinjauan pustaka diperoleh beberapa kriteria atau parameter penelitian untuk mengetahui manfaat yang diperoleh masyarakat dari bangunan pengendali banjir yang ada dan mengetahui kepuasan masyarakat dari adanya bangunan pengendali banjir.

\section{Menarik Kesimpulan}

Pada akhir penelitian penulis menyimpulkan hasil dari penelitian dan memberikan saran agar konstruksi pengendali banjir dapat tepat guna pada masyarakat.

\section{HASIL DAN PEMBAHASAN}

\section{Profil Infrastruktur Pengendali Banjir}

Sungai Bungus, Kecamatan Bungus Teluk Kabung, Kota Padang dengan panjang sekitar 16.200 meter tersebut, terdiri dari dua infrastruktur pengendali banjir yaitu normalisasi berupa dinding penahan tebing sungai dan bronjong sepanjang tiga kilometer serta infrastruktur checkdam (Gambar 1). Infrastruktur pengendali banjir tersebut dilakukan secara bertahap dengan anggaran APBD Kota Padang dan APBD Provinsi Sumatera Barat. Anggaran infrastruktur normalisasi dengan nilai proyek 7 Miliar Rupiah dan infrastruktur checkdam dengan nilai proyek 6 Miliar Rupiah (Dinas PSDA Sumbar, 2017).

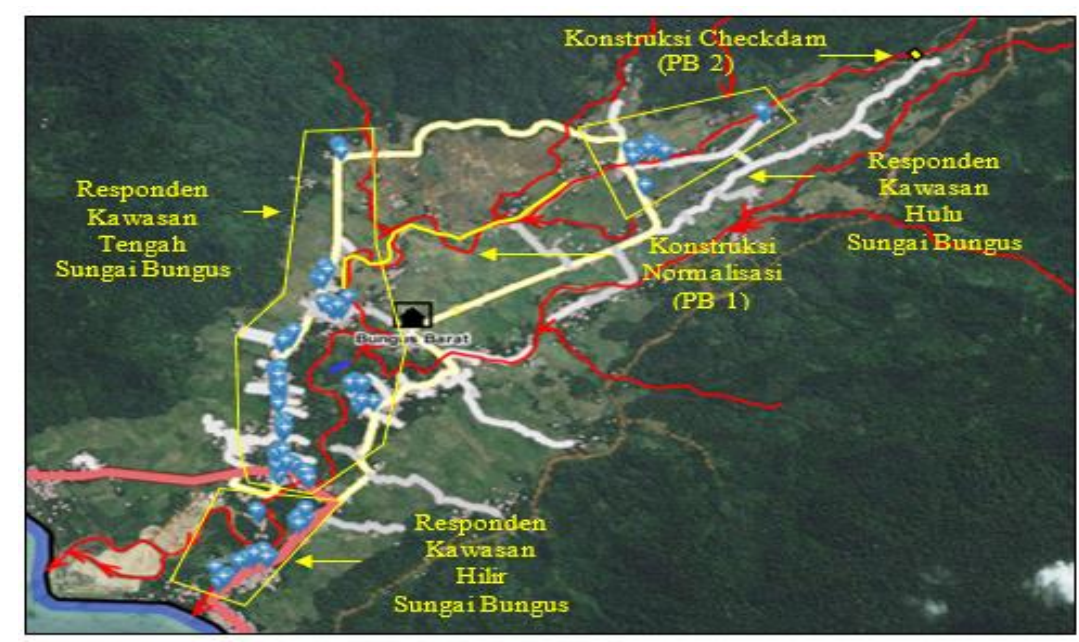

Sumber : pengolahan data dari software JOSM (Java Open Street Map) (2019)

Gambar 1. Denah Infrastruktur Pengendali Banjir dan Pembagian Responden 
M. Arifin et al, Tingkat Kepuasan Masyarakat terhadap Konstruksi Pengendali Banjir di Kawasan Sungai Bungus Kecamatan Bungus Teluk Kabung

\section{Profil Responden}

Jumlah masyarakat di kawasan Sungai Bungus yang dijadikan sebagai responden bejumlah 100 orang.

Tabel 1. Pembagian Jumlah Responden

\begin{tabular}{cc}
\hline Pembagian Wilayah & Jumlah \\
\hline Hulu & 13 \\
Tengah & 55 \\
Hilir & 32 \\
Total & $\mathbf{1 0 0}$ \\
\hline
\end{tabular}

Sumber: Pengolahan data (2019)

Berdasarkan hasil penelitian di lapangan, secara garis besar masyarakat di kawasan Sungai Bungus merupakan kawasan tertinggal secara pendidikan dengan rata - rata pendidikan terakhir responden adalah Sekolah Dasar (SD) yaitu 39\% dari total 100 responden. Hal ini juga dipengaruhi oleh kondisi jauhnya jarak administrasi dengan pusat pemerintahan kota padang yaitu sekitar $21 \mathrm{~km}$ dan dari data sensus terakhir tercatat 25 fasilitas pendidikan di kawasan Sungai Bungus dengan fasilitas pendidikan tertinggi yaitu SMA sebanyak 1 buah. Dari hasil tersebut dapat disimpulkan untuk fasilitas pendidikan di masyarakat Bungus minim ditambah jauhnya jarak administrasi dengan pemerintahan pusat Kota Padang.

\section{Tinggi Banjir}

Hal ini menggambarkan infrastruktur pengendali banjir cukup efektif untuk mengatasi banjir pada kawasan Sungai Bungus. Terlihat sebelum adanya infrastruktur pengendali banjir rata-rata ketinggian banjir $40 \mathrm{~cm}$, setelah adanya infrastruktur normalisasi menjadi $32 \mathrm{~cm}$ dan terus menurun menjadi $0 \mathrm{~cm}$ setelah adanya infrastruktur checkdam.

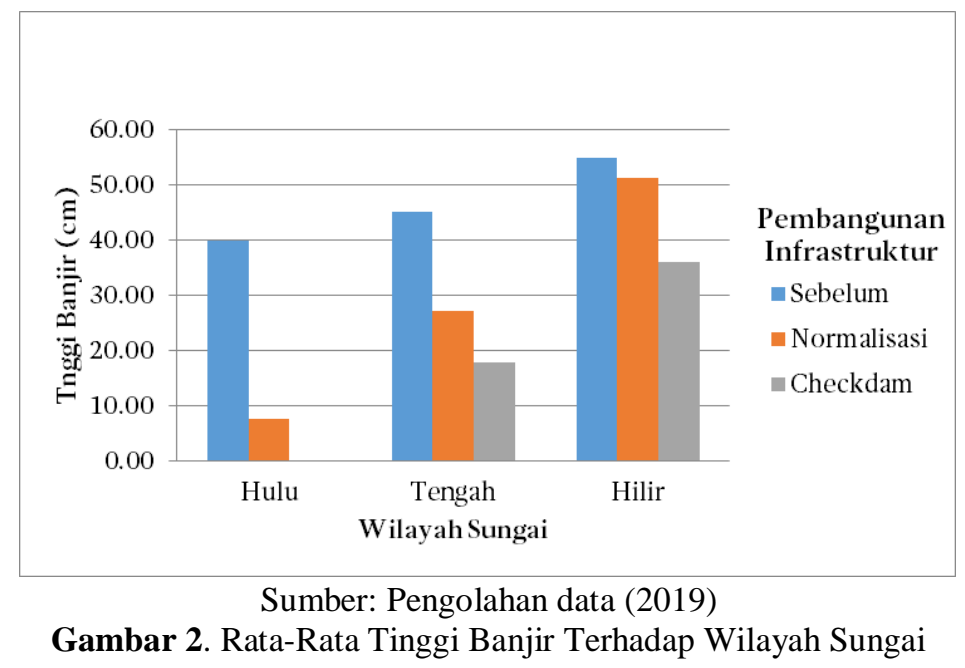

\section{Peta Banjir}

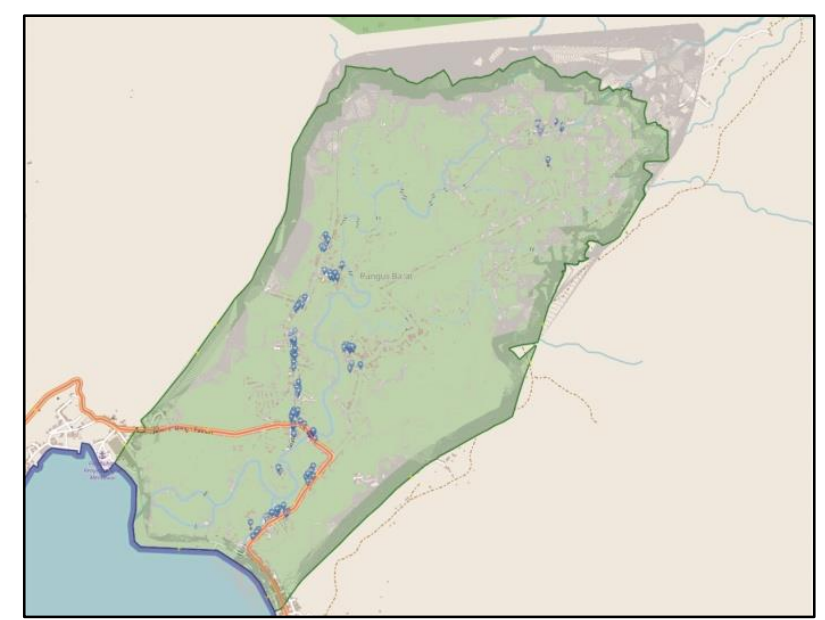

Sumber : pengolahan data dari software JOSM (Java Open Street Map) (2019)

Gambar 3. Peta Luas Banjir dengan Ketinggian 0 - 14 Sentimeter sebelum ada infrastruktur pengendali banjir 


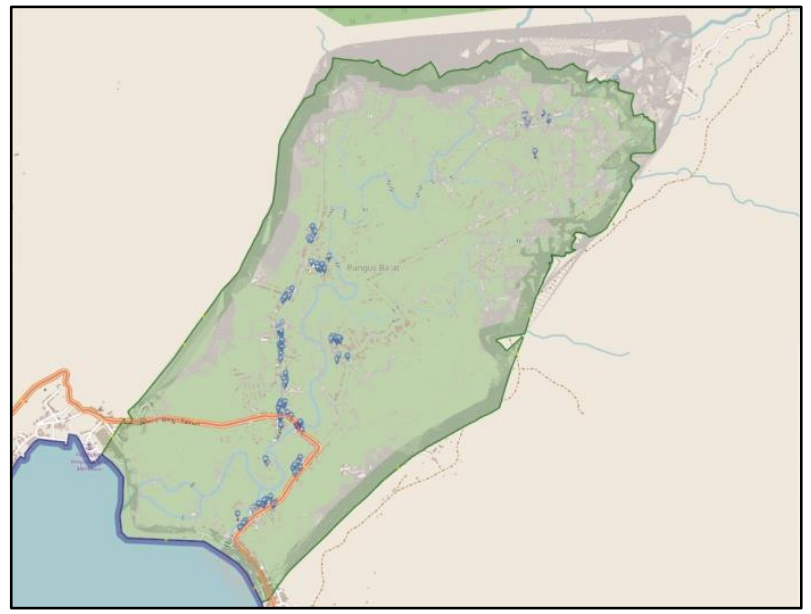

Sumber : pengolahan data dari software JOSM (Java Open Street Map) (2019)

Gambar 4. Peta Luas Banjir dengan Ketinggian 0 - 14 Sentimeter setelah pembangunan insfrastruktur pengendali banjir pertama

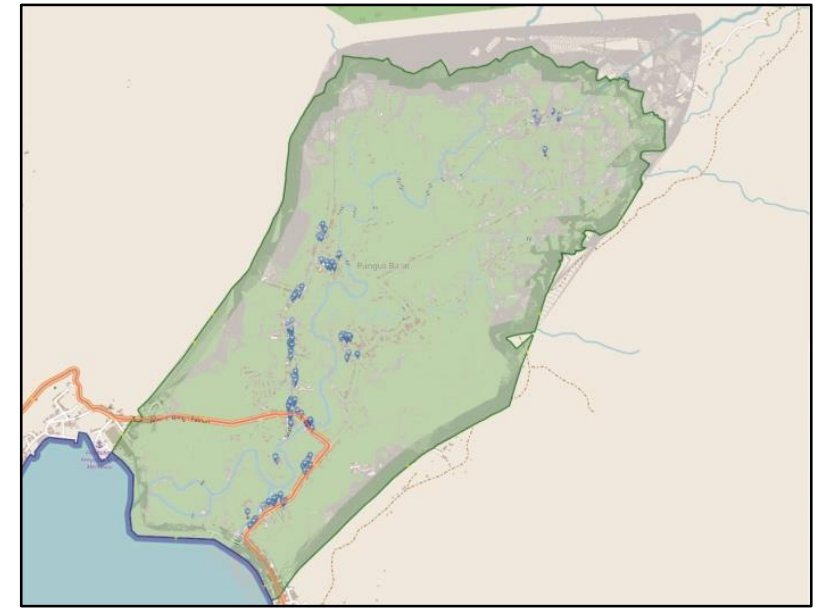

Sumber : pengolahan data dari software JOSM (Java Open Street Map) (2019)

Gambar 5. Peta Luas Banjir dengan Ketinggian $0-14$ Sentimeter setelah pembangunan insfrastruktur pengendali banjir kedua

Tabel 2. Prestasi Peningkatan Pengurangan Luas Banjir per Ketinggian Banjir

\begin{tabular}{cccc}
\hline Ketinggian Banjir $(\mathbf{c m})$ & S - PB1 $\left.\mathbf{( k m}^{\mathbf{2}}\right)$ & $\mathbf{S ~ - ~ P B 2 ~}\left(\mathbf{k m}^{\mathbf{2}}\right)$ & PB2 $-\mathbf{P B 1}(\mathbf{k m})$ \\
\hline$<15$ & 2.589 & 2.589 & 0 \\
$15-50$ & 1.385 & 5.706 & 4.321 \\
$>50$ & 1.063 & 1.739 & 0.676 \\
\hline
\end{tabular}

Sumber: Pengolahan data (2019)

Keterangan : $\mathrm{S}=$ Sebelum ada pengendali banjir, PB1 = Normalisasi, PB2 = Checkdam

Nilai prestasi didapatkan dari perhitungan peningkatan pengurangan luas banjir tiap bangunan pengendali banjir terhadap sebelum adanya infrastruktur pengendali banjir dengan normalisasi, antara normalisasi dan checkdam serta dari sebelum ada infrastruktur pengendali banjir dengan checkdam atau dapat disebut hasil akhir prestasi pengendali banjir yang sudah ada di Sungai Bungus. Dapat disimpulkan dari awal sebelum adanya infrastruktur pengendali banjir dibandingkan dengan seluruh infrastruktur pengendali banjir yang ada di Sungai Bungus, prestasi yang mampu dihasilkan yaitu pada ketinggian banjir di bawah 15 sentimeter menghasilkan prestasi 2.589 km2, pada ketinggian antara 15 sampai 50 sentimeter memiliki prestasi $5.706 \mathrm{~km} 2$, dan pada ketinggian diatas 50 sentimeter diperoleh hasil seluas $1.739 \mathrm{~km} 2$. 


\section{Analisa Statistik dalam Bentuk Grafik}

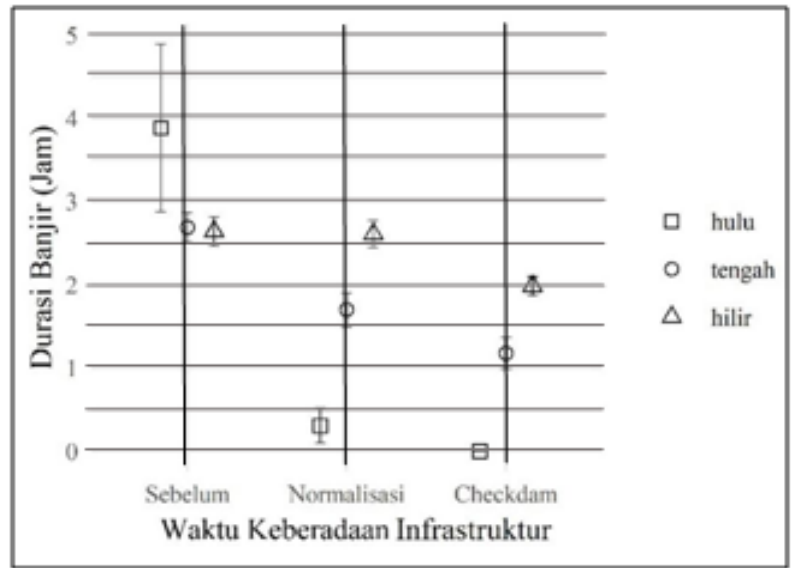

Sumber: Pengolahan data dengan software Rstudio (2019)

Gambar 6. Perbandingan durasi banjir dengan waktu keberadaan infrastruktur pada wilayah sungai Keterangan : garis tengah pada tiap wilayah sungai adalah standar error variabel

Pada wilayah hulu memiliki nilai rata - rata sebelum ada infrastruktur adalah 3 jam 53 menit, setelah ada normalisasi 0 jam 18 menit dan setelah ada checkdam 0 jam. Pada daerah tengah sungai, nilai rata - rata sebelum ada infrastruktur adalah 2 jam 41 menit, setelah normalisasi 1 jam 42 menit dan setelah checkdam 1 jam 11 menit. Pada daerah hilir, nilai rata - rata sebelum ada infrastruktur adalah 2 jam 38 menit, setelah normalisasi 2 jam 36 menit, setelah checkdam 1 jam 59 menit. Dapat disimpulkan pada daerah hulu sungai terjadi penurunan yang drastis setelah adanya normalisasi bahkan setelah adanya checkdam tidak terendam banjir sama sekali. Namun juga terdapat penurunan rata - rata ketinggian banjir pada wilayah tengah dan hilir sungai walaupun nilainya tidak terlalu besar.

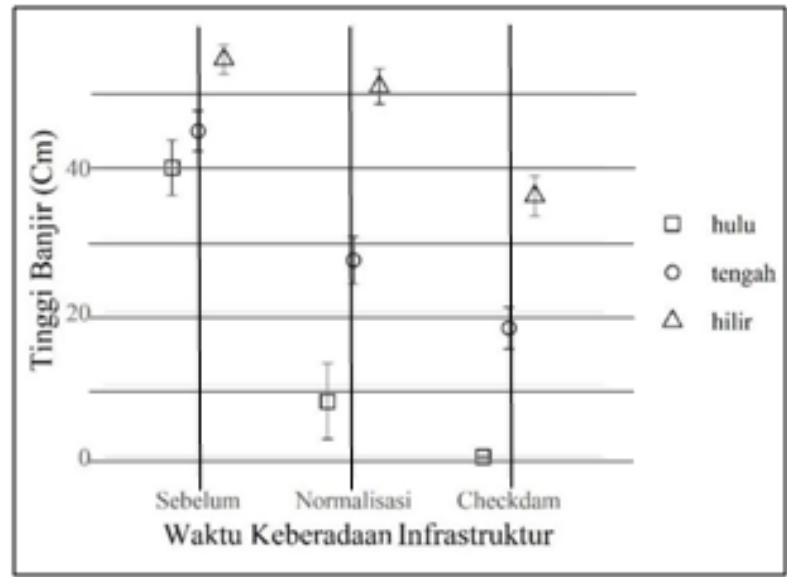

Sumber: Pengolahan data dengan software Rstudio (2019)

Gambar 7. Perbandingan tinggi banjir dengan waktu keberadaan infrastruktur pada wilayah sungai

Tinggi banjir rata - rata pada daerah hulu sebelum adanya infrastruktur pengendali banjir adalah 40 sentimeter, setelah normalisasi menjadi 7.69 sentimeter dan setelah checkdam tidak lagi terjadi banjir. Pada daerah tengah sungai, tinggi rata - rata sebelum ada infrastruktur pengendali banjir adalah 45.09 sentimeter, setelah normalisasi menjadi 27.2 sentimeter, setelah checkdam menjadi 17.81 sentimeter. Pada hilir sungai, tinggi banjir rata - rata sebelum ada infrastruktur pengendali banjir adalah 55 sentimeter, setelah ada normalisasi menjadi 51.25 sentimeter, setelah checkdam menjadi 36.09 sentimeter. Dari grafik dapat disimpulkan penurunan tinggi banjir yang paling besar terjadi pada wilayah hulu sungai setelah adanya normalisasi, bahkan setelah adanya chekdam tidak ada kejadian banjir sama sekali. Pada wiayah tengah dan hilir juga terdapat penurunan rata - rata tinggi banjir walaupun nilainya tidak terlalu signifikan. Perlu diperhatikan pada wilayah hilir sungai setelah adanya normalisasi, dapat dilihat rata - rata tinggi banjir dibandingkan dengan sebelum adanya normalisasi tidak terlalu jauh penurunannya dengan perbedaan hanya 3.75 sentimeter. Hal ini dikarenakan tidak adanya normalisasi di daerah hilir dimana tidak adanya peningkatan kapasitas daya tampung sungai seperti di daerah hulu dan hilir serta diperparah oleh adanya pasang air laut yang menyebabkan durasi tergenang dan tinggi banjir masih terbilang cukup tinggi pada wilayah tersebut. 


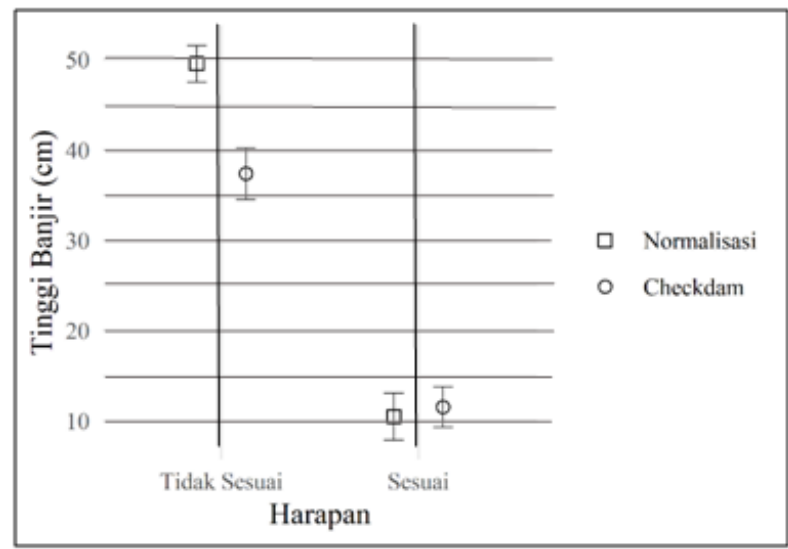

Sumber: Pengolahan data dengan software Rstudio (2019)

Gambar 8. Perbandingan tinggi banjir terhadap kesesuaian harapan berdasarkan keberadaan infrastruktur

Responden yang mewakili persepsi masyarakat pada wilayah tersebut menyatakan kesesuaian harapan dengan adanya normalisasi ketika rata - rata tinggi banjir yang menggenangi rumah responden pada ketinggian 10.47 sentimeter. Setelah adanya checkdam, responden yang mengatakan kesesuaian harapannya ketika tinggi banjir rata rata yang menggenangi rumah responden berada pada ketinggian 11.53 sentimeter.

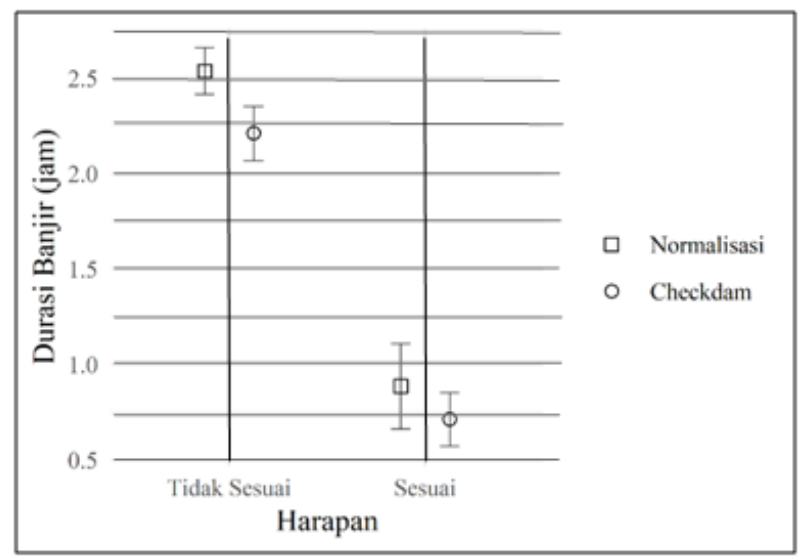

Sumber: Pengolahan data dengan software Rstudio (2019)

Gambar 9. Perbandingan durasi banjir terhadap kesesuaian harapan berdasarkan keberadaan infrastruktur

Normalisasi dapat memenuhi kesesuaian harapan masyarakat ketika berada pada durasi rata - rata banjir selama 53 menit dan 43 menit ketika setelah adanya checkdam.

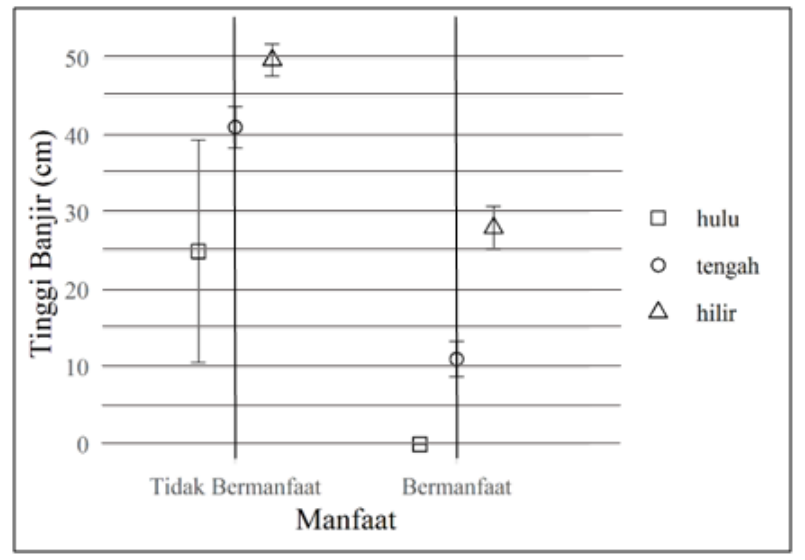

Sumber: Pengolahan data dengan software Rstudio (2019)

Gambar 10. Perbandingan tinggi banjir terhadap manfaat infrastruktur berdasarkan wilayah sungai

Berdasarkan kalkulasi program didapatkan hasil, pada wilayah hulu masyarakat menyatakan adanya manfaat dengan adanya kedua infrastruktur pengendali banjir tersebut ketika rata - rata tinggi banjir berada pada 0 sentimeter 
atau dapat disebutkan tidak terjadi banjir. Menurut wilayah tengah masyarakat menyatakan sudah adanya manfaat dengan keberadaan kedua infrastruktur tersebut ketika ketinggian rata - rata banjir berada pada 11.04 sentimeter. Pada wilayah hilir sungai, masyarakat yang menyatakan sudah adanya manfaat dengan keberadaan kedua infrastruktur pengendali banjir tersebut ketika rata - rata ketinggian banjir yang terjadi berada pada 28.05 sentimeter.

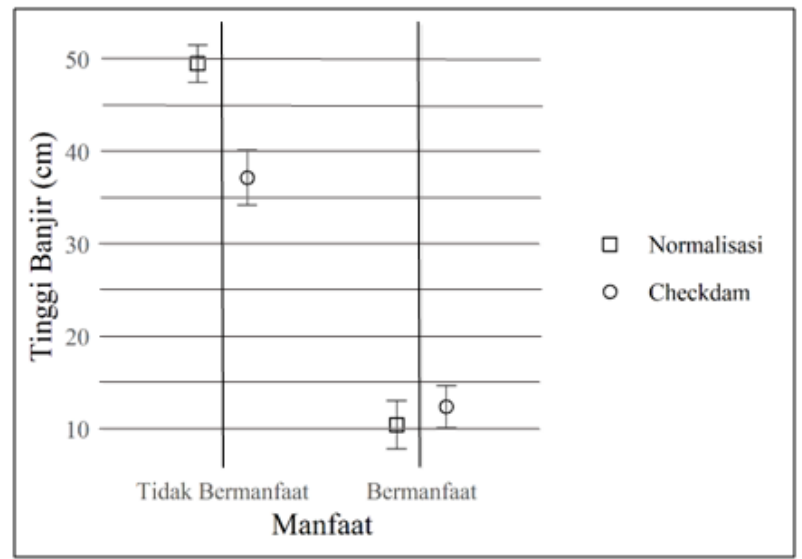

Sumber: Pengolahan data dengan software Rstudio (2019)

Gambar 11. Perbandingan tinggi banjir terhadap manfaat infrastruktur berdasarkan waktu keberadaan infrastruktur

Responden yang mewakili persepsi masyarakat pada wilayah tersebut menyatakan adanya manfaat dengan adanya normalisasi ketika rata - rata tinggi banjir yang menggenangi rumah responden berada pada ketinggian 10.02 sentimeter. Sedangkan setelah adanya checkdam, responden yang menyatakan adanya manfaat adanya checkdam tersebut ketika tinggi banjir rata - rata yang menggenangi rumah responden berada pada ketinggian 12.42 sentimeter.

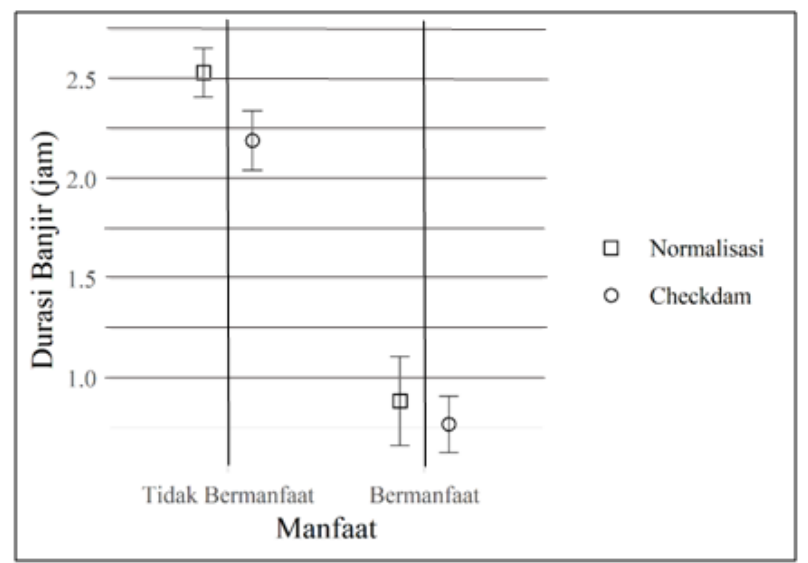

Sumber: Pengolahan data dengan software Rstudio (2019)

Gambar 12. Perbandingan Durasi banjir terhadap manfaat infrastruktur berdasarkan waktu keberadaan infrastruktur

Normalisasi dapat memenuhi kesesuaian harapan masyarakat ketika berada pada durasi rata - rata banjir selama 50 menit dan 46.2 menit ketika setelah adanya checkdam.

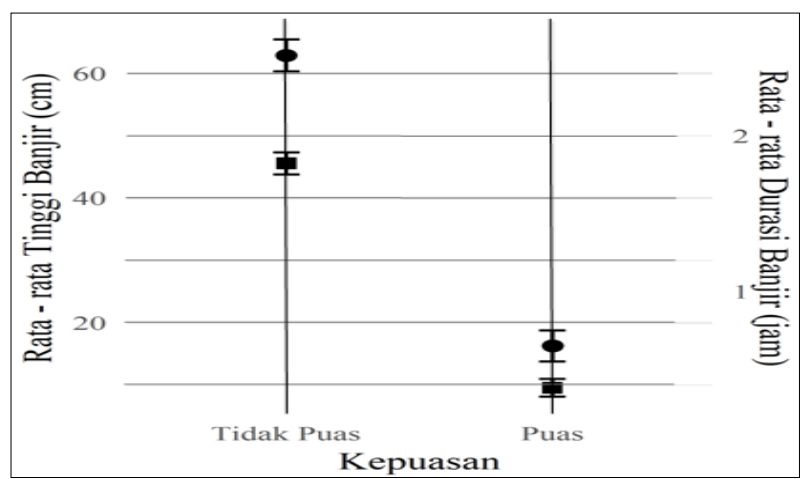

Sumber: Pengolahan data dengan software Rstudio (2019)

Gambar 13. Perbandingan tinggi dan durasi banjir terhadap kepuasan masyarakat 
Dari pengkalkulasian sowfware di atas, didapatkan pola bahwa responden menyatakan kepuasannya ketika rata - rata tinggi banjir berada pada ketinggian $9.57 \mathrm{~cm}$ dan rata - rata durasi banjir selama 38 menit.

\section{SIMPULAN}

1. Dari kedua infrastruktur yang ada, masyarakat merasakan manfaat yang berbeda. Khusus untuk infrastruktur normalisasi mayarakat belum merasakan manfaat ketika hanya ada konstruksi normalisasi tersebut, terutama bagi masyarakat yang berada di wilayah tengah dan hilir badan sungai. Hal ini dikarenakan letak normalisasi hanya pada kawasan hulu sungai. Namun, setelah adanya infrastruktur checkdam, secara keseluruhan masyarakat sudah merasakan manfaat dari infrastruktur tersebut.

2. Masyarakat merasa tidak puas ketika hanya ada infrastruktur normalisasi pada sungai tersebut terlebih pada wilayah tengah dan hilir. Hal ini disebabkan karena setelah adanya infrastruktur tersebut malah menambah jumlah kejadian dan ketinggian banjir, dimana bagian tengah dan hilir sungai tidak mampu menampung aliran air dari bagian hulu sungai yang sudah ada infrastruktur normalisasi. Namun setelah adanya infrastruktur checkdam masyarakat merasakan adanya penurunan intensitas dan ketinggian banjir sehingga masyarakat puas dengan adanya infrastruktur pengendali banjir berupa checkdam tersebut.

3. Dapat disimpulkan kepuasan masyarakat terhadap infrastruktur pengendali banjir berbanding lurus dengan keberhasilan infrastruktur tersebut dalam mengatasi banjir di kawasan Sungai Bungus. Semakin efektif suatu infrastruktur pengendali banjir dalam mengatasi banjir maka semakin tinggi kepuasan masyarakatnya demikian sebaliknya

4. Prestasi luasan banjir yang mampu dihasilkan dari infratruktur pengendali banjir yang sudah ada sampai saat ini pada Sungai Bungus dibandingkan dengan sebelum adanya infrastruktur pengendali banjir yaitu pada ketinggian banjir dibawah 15 sentimeter menghasilkan prestasi seluas $2.589 \mathrm{~km} 2$, pada ketinggian antara 15 sampai 50 sentimeter memiliki presrasi seluas $5.706 \mathrm{~km} 2$, dan pada ketinggian diatas 50 sentimeter diperoleh hasil seluas $1.739 \mathrm{~km} 2$

\section{DAFTAR PUSTAKA}

Bahtiar, A. 2010. Simulasi Pemilihan Desain dan Perencanaan Teknis Retarding Pond di Kelurahan Mintaragen Kota Tegal. Universitas Diponegoro. Semarang.

Badan Pusat Statistik Kota Padang. 2017. Kecamatan Bungus Teluk Kabung Dalam Angka. Padang.

Badan Pusat Statistik Kota Padang. 2016. Statistik Daerah Kecamatan Bungus Teluk Kabung. Padang.

Peraturan Kepala Badan Nasional Penanggulangan Bencana Nomor 02 Tahun 2012 tentang Pedoman Umum Pengkajian Risiko Bencana.

Prasetyo, Bambang dkk. 2012. Metode Penelitian Kuantitatif. Jakarta. PT Raja Grafindo Persada.

Sugiyono. 2013. Metode Penelitian Manajemen : Pendekatan Kuantitatif, Kualitatif, Kombinasi, Penelitian Tindakan dan Penelitian Evaluasi. Bandung. Alfabeta.

Supranjo, J. 1998. Teknik Sampling Untuk Survei dan Eksperimen. Jakarta. Rineka Cipta. 